\title{
Constitutional Courts and Judicial Law-Making: Why Democratic Legitimacy Matters
}

\author{
Anna Gamper*
}

\begin{abstract}
Law-making, understood as the process of making, amending or abrogating laws, is traditionally conceived as the domain of the legislative power and not that of the judiciary, even though courts certainly make law inasmuch as they create and enact their own judgments. But even the making of laws may fall into different spheres of power, depending on whether we conceptualise legislation from an organisational or functional viewpoint. Firstly, this article distinguishes six different types of judicial law-making by constitutional courts from a comparative perspective. Secondly, it critically assesses the significance of judicial input both in the pre- and post-enactment phase of legislation vis-à-vis the democratic legitimacy of constitutional courts. The argument here is that constitutional courts, as organisational structures, can hardly ever claim the same democratic legitimacy as is usual for other bodies involved in law-making processes. Thirdly, the article addresses the question of whether constitutional courts are able to compensate for this deficit through their function as protectors of the constitution, and whether this democratic function legitimises all types of judicial law-making.
\end{abstract}

\section{Keywords}

Constitutional Courts, Negative Legislation, Positive Legislation, Interpretation, Separation of Powers, Judicial Review, Democracy

A constitution is, in fact, and must be regarded by the judges, as a fundamental law. It therefore belongs to them to ascertain its meaning, as well as the meaning of any particular act proceeding from the legislative body. If there should happen to be an irreconcilable variance between the two, (...) the Constitution ought to be preferred to the statute. (...) Nor does this conclusion by any means suppose a superiority of the judicial to the legislative power. It only supposes that the power of the people is superior to both; and that where the will of the legislature, declared in its statutes, stands in opposition to that of the people, declared in the Constitution, the judges ought to be governed by the latter rather than the former. ${ }^{1}$

* Professor, Department of Public Law, State and Administrative Theory, University of Innsbruck (Austria). Many thanks go to Teresa Sanader for her valuable help in editing the footnotes.

1 Alexander Hamilton, The Federalist Papers (McLean's 1788) No 78. 


\section{Introduction}

In terms of the classical separation of powers, judicial law-making at first appears as a contradictio in adiecto. At least, law-making, understood as the process of making, amending or abrogating laws, is naturally conceived of as the domain of the legislative power and not that of the judiciary, even though courts certainly make law inasmuch as they create and enact their own judgments. ${ }^{2}$ But even the making of laws may fall into different spheres of power, depending on whether we conceptualise legislation from an organisational or functional viewpoint. Firstly, therefore, this article seeks to distinguish six different types of judicial ${ }^{3}$ law-making ${ }^{4}$ by constitutional courts ${ }^{5}$ from a comparative perspective. Secondly, it will critically assess the significance of judicial input both in the pre- and post-enactment phase of legislation vis-à-vis the democratic legitimacy of constitutional courts. The argument here is that constitutional courts, as organisational structures, can hardly ever claim the same democratic legitimacy as is usual for other bodies involved in law-making processes. The article will, thirdly, address the question of whether constitutional courts are able to compensate for this deficit through their function as protectors of the constitution, and whether this democratic function legitimises all types of judicial law-making.

\section{Classifying judicial law-making}

\subsection{Negative legislation}

The primary power of a constitutional court is the constitutional review of laws. ${ }^{6}$ This usually vests the court with a function which Hans Kelsen called that of a 'negative

2 On the law-creating-and not just law-applying-function of courts, see Hans Kelsen, Allgemeine Staatslehre (J Springer 1925) 229-31; Hans Kelsen, 'Wesen und Entwicklung der Staatsgerichtsbarkeit' in Vereinigung der Deutschen Staatsrechtslehrer (ed), Veröffentlichungen der Vereinigung der Deutschen Staatsrechtslehrer, vol 5 (De Gruyter 1929) 30-32.

3 The political influence exerted by constitutional courts and their judges that may have an informal impact on legislation will not be examined here.

4 This is understood as the making or unmaking of laws in a sense equivalent to a legislature. This article therefore examines more than just cases of 'positive' legislation while it does not regard all possible categories of judicial decision-making as 'law-making. For a different focus, see Allan R Brewer-Carías, 'Constitutional Courts as Positive Legislators in Comparative Law' in Allan R Brewer-Carías (ed), Constitutional Courts as Positive Legislators: A Comparative Law Study (CUP 2013) 13-188.

5 Although the term usually refers to specialised constitutional review, here it is also applied to courts under the integrated model as far as this is compatible. See Andrew Harding and others, 'Constitutional Courts: Forms, Functions and Practice in Comparative Perspective' (2008) J Comp L 1, 2-5; Víctor Ferreres Comella, 'The Rise of Specialized Constitutional Courts' in Tom Ginsburg and Rosalind Dixon (eds), Comparative Constitutional Law (Edward Elgar Publishing 2011) 265-66; Alec Stone Sweet, 'Constitutional Courts' in Michel Rosenfeld and András Sajó (eds), The Oxford Handbook of Comparative Constitutional Law (OUP 2012) 817-20.

6 Ferreres Comella (n 5) 266-68; Stone Sweet (n 5) 822-23; Harding and others (n 5) 6. 
legislator', namely, not a maker, but 'unmaker' of laws which the court holds to be unconstitutional. ${ }^{7}$ Although the term is rather catchy, it needs some clarification. First of all, it only applies to those courts that enjoy some kind of strong-form judicial review, ${ }^{8}$ which allows them to repeal ${ }^{9}$ laws. Courts that are only entitled to weak-form review, ie to interpret laws so as to make them consistent with the superior law or to appeal to Parliament by a declaration of incompatibility, ${ }^{10}$ are not negative legislators in the true sense of the word, even though their review may have some indirect impact on the law. ${ }^{11}$ Even where courts exercise strong-form review and thus have the power to repeal a law, their role as negative legislators is not simply a mirror image of the positive legislator. ${ }^{12}$ The only option for them is to state whether the law is constitutional or not, ${ }^{13}$ which in the latter case implies a repeal of that law.

In contrast, a positive legislator has much more choice; the creative selection between (almost) endless options of design and content of a law is naturally different from the simple choice between the verdict of constitutionality or unconstitutionality. Moreover, while the process of positive legislation does not necessarily undergo negative legislation afterwards, negative legislation at any rate presupposes a previous act of positive legislation. While positive legislation normally needs a complex process consisting of different phases and involved legislative organs, negative legislation by courts is much simpler and performed by them single-handedly. Constitutional courts are, however, always rivalled by other negative legislators, namely, the law-maker itself that is not prevented from repealing a law of its own free will-which, paradoxically, needs a positive law-making process in order to enact a law that ends the validity of the

7 See, eg, Kelsen, 'Wesen und Entwicklung der Staatsgerichtsbarkeit' (n 2) 56.

8 Mark Tushnet, Weak Courts, Strong Rights: Judicial Review and Social Welfare Rights in Comparative Constitutional Law (Princeton UP 2008); Mark Tushnet, 'The Rise of Weak-form Judicial Review' in Tom Ginsburg and Rosalind Dixon (eds), Comparative Constitutional Law (Edward Elgar Publishing 2011) 323; Albert HY Chen and Miguel Poiares Maduro, 'The Judiciary and Constitutional Review' in Mark Tushnet and others (eds), Routledge Handbook of Constitutional Law (Routledge 2013) 102-03.

9 For the sake of clarity of language, the term 'repeal', as used here and throughout the text, comprises all forms of an erga omnes invalidation of a law.

10 See, eg, Human Rights Act 1998 (UK) ss 3-4; Tushnet, 'The Rise of Weak-form Judicial Review' (n 8) 323-26 (distinguishing between three different types of weak-form review, including also a type such as the Canadian 'notwithstanding clause'). See also Chen and Poiares Maduro (n 9) 103.

11 On the particular opportunities for dialogue between courts and legislatures emerging from weak-form review, see Tushnet, 'The Rise of Weak-form Judicial Review' (n 8) 325-27.

12 See Kelsen, 'Wesen und Entwicklung der Staatsgerichtsbarkeit' (n 2) 56.

13 Constitutional courts may often decide on whether a repeal has retrospective effect or whether the norm ceases to be in force at a later date after the judgment. See, from a comparative perspective, Patricia Popelier and others (eds), The Effects of Judicial Decisions in Time (Intersentia 2013); Wen-Chen Chang and others (eds), Constitutionalism in Asia: Cases and Materials (Hart Publishing 2014) 447-56; Daniele Butturini and Matteo Nicolini (eds), Tipologie ed Effetti Temporali delle Decisioni di Incostituzionalità: Percorsi di Diritto Costituzionale Interno e Comparato (Edizioni Scientifiche Italiane 2014). These ancillary competences, however, are tangential to the power of repeal and do not constitute any kind of positive legislation, since they can just mitigate negative legislation (similarly, Brewer-Carías (n 4) 94). 
previous law. In contrast, it would appear at first glance that positive law-makers have no rival, but this assertion will be put under critical test later. ${ }^{14}$

An as yet neglected aspect of negative legislation by constitutional courts is the question of whether this function is necessarily limited to the post-enactment phase of legislation. Normally, it would seem, constitutional courts repeal a law after and because of its enactment. If we think, however, of those not infrequent cases where constitutions entitle constitutional courts to exercise ex ante review of draft laws, ${ }^{15}$ negative legislation might to some extent be even part of a pre-enactment process. Constitutions vary as to whether they make such ex ante review compulsory or dependent on the decision of other organs and whether the relevant constitutional court's negative assessment of a draft law has binding force, ie absolutely stops the legislative process, or just requires the legislative organs to reflect on the assessment before they decide in accordance with their own wishes. Constitutions often respect the separation of powers inasmuch as a court's assessment of a draft law does not absolutely prevent the law-maker from enacting the law. ${ }^{16}$ But it is questionable whether the court's decision, even if it had an absolute and binding impact, could really constitute negative legislation. If constitutional courts repeal a law after its enactment, this will be negative legislation because the court eliminates an existing law. In a phase when the law has not yet been enacted we cannot properly speak of 'negative legislation', because it is not a law that is declared invalid, but a draft that is prevented from becoming a law. If we accepted this term, all kinds of deadlocks and vetoes in such a process would constitute 'negative legislation'. This would, however, unduly confuse the particular function of a constitutional court in the post-enactment phase of legislation with the political veto-stages of the creation of a law.

\subsection{Positive legislation as entailed by negative legislation}

Paradoxically, a possibility for a constitutional court to act as positive legislator could emanate from its negative legislation. When a law is repealed, the question might arise

14 See below 2.6-2.7.

15 An ex ante review of laws by judicial bodies is, eg, provided by the constitutions of Angola, Benin, Bolivia, Bulgaria, Burundi, Chad, Chile, Colombia, Congo, Cyprus, Djibouti, Ecuador, Estonia, Finland, Gabon, France, Haiti, Hungary, Ireland, Madagascar, Mali, Mauritania, Moldova, Poland, Portugal, Romania, Senegal, Somalia, Sweden, Syria and Zimbabwe. Sometimes, an ex ante review of laws is only required for regional laws (see, eg, Scotland Act 1998 (UK) ss 32-33 and 36; Government of Wales Act 2006 (UK) ss 111-12; Northern Ireland Act 1998 (UK) ss 11-13) or in the context of competence conflicts (see Austrian Federal Constitutional Act, art 138(2)). Stone Sweet (n 5) 823 calls the ex ante review 'abstract review', which, however, confuses two different matters. Ex ante review comprises all kinds of review by constitutional courts before a law is enacted (see Chen and Poiares Maduro (n 8) 102), while abstract review refers to the fact that a law is reviewed without its concrete application in the course of litigation. Although abstract review comprises ex ante review, it also comprises ex post review, provided that certain organs uninvolved in litigation, such as parliaments or governments, are entitled to request a constitutional review.

16 In contrast, an absolute preventive power is, eg, provided by s 144(2) of the Constitution of South Africa, according to which no text of a provincial constitution or constitutional amendment becomes law until the Constitutional Court has given its certification. 
whether a previous law that had been amended or revoked by that law will be automatically reinstated or not, and whether the constitutional court will have discretion to decide on this issue. An example is article 140(6) of the Austrian Federal Constitutional Act according to which a previous law will once again become operative if the revoking law is itself repealed by the Constitutional Court-unless the Constitutional Court decides otherwise. Paradoxically, this implies that it would need a positive action of the Court to confirm some kind of negative legislation apart from the negative legislation stemming from the repeal of the revoking law. If the Constitutional Court decides not to enact such a provision, the previous law will be re-enacted ex constitutione, while it will not be re-enacted if the Constitutional Court does so decide. This implies, on the one hand, that the Constitutional Court may be a negative legislator, if it positively prohibits the re-enactment of the previous law; and that it will be a 'confirmative' positive legislator, if it remains passive-ie simply allows the previous law to become operative following the repeal of the revoking law. And yet, the Constitutional Court will not become a genuine positive legislator even if it chooses the latter option, because the Court cannot of its own create a law with whatever content. Moreover, the re-enactment does not result from a positive decision to re-enact the law, but from the Court's decision not to counteract the re-enactment as an ex constitutione corollary. The legislature may also enact another law that either terminates, reinstates or replaces the previous law despite the Constitutional Court's decision.

Similarly, article 282(1) of the Portuguese Constitution provides that a declaration of unconstitutionality or illegality with generally binding force shall cause the revalidation of such rules as the unconstitutional rule may have revoked. According to article 282(4), however, the Constitutional Court may rule that the scope of the effects of the unconstitutionality or illegality shall be more restricted when so required for the purposes of legal certainty, reasons of fairness or an exceptionally important public interest.

The particularly interesting feature of this power lies in its Janus-faced character. The re-enactment follows an act of negative legislation by the constitutional court, and that court may then decide whether to allow or prevent that re-enactment, being, however, limited to a 'yes/no' determination and rivalled by the legislature.

If, however, a constitutional court repeals just one or several provisions, while the law as such remains, the remaining provisions might get a more or less different meaning, because the context will be changed. Even though courts may seek to adapt the scope of the repeal in order to avoid this change of meaning as far as possible, the repeal will always have some impact on the remaining provisions of a law. Therefore, despite the court not positively changing the text of the remaining law, its interpretation may become different after the repeal. It will be for the constitutional court to balance the scope of the repealed provisions with the risk of a change of meaning, ${ }^{17}$ even though this must not prevent the court from repealing all that is unconstitutional.

17 A constitutional court might thus repeal even a little more than just the unconstitutional provision, if this would help maintain the previous meaning (see, eg, the established 'balancing formula' used in the context 


\subsection{Pre-enactment scrutiny}

As mentioned earlier, ${ }^{18}$ the pre-enactment scrutiny of draft laws does not vest constitutional courts with the function of a negative legislator, since there is no legislation yet that could be 'unmade' and their ex ante decisions often have persuasive rather than binding authority on a legislature. The question is, however, whether the power of preenactment scrutiny bestows on them a positive law-making function. Although it may be doubtful whether a court's negative assessment that a draft law would be unconstitutional could be subsumed as a 'positive' contribution to the creation of that law, this may be different when a constitutional court replies in the affirmative, namely, that the draft law is consistent with the constitution; or it could, in case of a negative assessment, trigger a re-drafting and renewed deliberation of the bill. Admittedly, the constitutional court would not act as an autonomous positive legislator in such a case, since the enactment of the law would essentially depend on the decision of other bodies, but the court would nonetheless contribute to positive legislation-even with a view to depriving itself of occasion for negative legislation; if a court certifies the constitutionality of the draft law, it will hardly repeal it as unconstitutional after its enactment.

\subsection{Legislative proposals}

While the previous cases discussed here relate to ex ante or ex post constitutional review as a classical function of constitutional courts, some constitutions provide for judicial law-making of a strikingly different nature. In these extremely rare cases, constitutional courts resemble positive legislators to a much closer degree, since they are engaged in the pre-enactment phase of legislation not as a reviewing body, but as a body that designs and initiates laws. ${ }^{19}$

According to article 134(4) of the Constitution of Ecuador, the Constitutional Court has the right to submit bills in the subjects that pertain to the Court in accordance with its competences. Similarly, article 104 of the Russian Constitution provides that the right of legislative initiative shall belong to the Constitutional Court on issues within its competence. An even wider empowerment can be derived from article 203 of the Constitution of Paraguay according to which the Supreme Court of Justice-which also exercises constitutional review-may propose laws 'in the cases and in the conditions specified in this Constitution and in the law' A specific right of the Constitutional Court to submit proposals for constitutional amendments is entrenched in article 68 of the Mongolian Constitution. Even though most constitutions do not provide for

of repeals by the Austrian Constitutional Court). As the interference with the legislative power will thus be the greater, this 'ancillary repeal' must be handled very carefully.

18 See above 2.1 .

19 Tom Ginsburg and Zachary Elkins, 'Ancillary Powers of Constitutional Courts' (2009) 87 Texas L Rev $1432,1444-45$. 
such rights, these examples show that constitutional courts are sometimes regarded as suitable initiators of legislation-in particular, if their expertise in constitutional affairs is considered to be valuable, such as in the context of constitutional amendments or of specific legislation on the constitutional courts themselves.

This is the only instance, however, where constitutional courts are involved in a positive law-making procedure without being restricted to constitutional review. In other words, these courts may positively design a law or constitutional amendment in accordance with their own 'political' views and not just review the constitutionality of a draft law submitted by another organ. However, this formal power to initiate laws must be distinguished from merely informal suggestions on how a new law could be formulated in order to be constitutional; such suggestions are sometimes included in constitutional courts' decisions on the unconstitutionality of a law. ${ }^{20}$ Even though these suggestions may have a political impact on the re-formulation of repealed laws, they are not legally binding, but rather offer some sort of advice to the positive law-maker.

\subsection{Substitute and mandated legislation}

While legislative proposals by constitutional courts do not necessarily become law, since this depends on the legislature's decision, constitutional courts in exceptional cases positively make laws without the assistance of any other legislative organ. What would normally appear as a serious violation of both democracy and the separation of powers, is considered to be legitimate in case of the legislature's omission to legislate. Such omissions will be particularly critical when constitutions entrench certain objectives or even human rights with the proviso that ordinary legislation needs to implement these constitutional guarantees in order for them to become operative. ${ }^{21}$ If the law-maker fails to do so, the constitutional guarantees will remain inapplicable.

20 ibid. A particularly far-reaching example is the 'admonitory decision' by the German Constitutional Court in which the Court, though it held a reviewed norm to be constitutional at the time of the review, suggests to the legislature to amend the norm in the future, because, with changing circumstances, it might become unconstitutional. See Ines Härtel, 'Germany: Constitutional Courts as Positive Legislators' in Allan R Brewer-Carías (ed), Constitutional Courts as Positive Legislators: A Comparative Study (CUP 2013) 514-15.

21 See, eg, Constitution of Ireland, art 45 ('The principles of social policy set forth in this Article are intended for the general guidance of the Oireachtas. The application of those principles in the making of laws shall be the care of the Oireachtas exclusively, and shall not be cognisable by any Court under any of the provisions of this Constitution'); Constitution of India, s 37 ('The provisions contained in this Part shall not be enforceable by any court, but the principles therein laid down are nevertheless fundamental in the governance of the country and it shall be the duty of the State to apply these principles in making laws'); Constitution of South Africa, ss 25-27 and s 29 (which entrench socio-economic rights requiring the state to take reasonable legislative and other measures, within its available resources, to achieve the progressive realisation of each of these rights, to foster conditions which enable citizens to gain access to land on an equitable basis or to further education, which must be made progressively available and accessible through reasonable measures). In many other cases, constitutions just entrench certain principles or directives without expressly declaring that they need to be implemented by ordinary legislation. A crucial question is whether the ordinary law-maker is absolutely obliged to enact implementing legislation or whether it is just obliged to consider certain principles when it enacts a law, and whether the implementation creates 
When such an omission is challenged before a constitutional court, most constitutional courts will be unable to enact legislation on behalf of the omitting lawmaker, although some of them will be able to hold that the constitution was violated by that omission and request the omitting law-maker to enact legislation within a certain time-limit. ${ }^{22}$ Other courts will not even be able to state an unconstitutionality, because they have no competence to examine a legal lacuna. ${ }^{23}$ Nevertheless, it has happened that a court decided not only that the omission was unconstitutional, but itself enacted substitute legislation as a provisional measure to remain valid until the 'true' law-maker had itself enacted implementing legislation. ${ }^{24}$ What is more, there are even constitutions that explicitly provide for such a possibility. Article 436(10) of the Constitution of Ecuador, for instance, empowers the Constitutional Court to declare the unconstitutionality incurred by state institutions or public authorities that fail to observe, either totally or partially, the mandates contained in constitutional rules, within the time limits deemed to be reasonable by the Constitutional Court. If this failure persists, after this time limit has elapsed, the Court shall provisionally issue the rule or enforce the observance in accordance with the law. In this case, the Constitutional Court may not only declare the unconstitutionality, but it is also empowered (and obliged) to enact substitute legislation. The only difference between such a judge-made law and a law enacted by the legislature is that it has a provisional nature-although not necessarily so, if the legislature, for whatever reason, remains inactive. A crucial question refers to the

justiciable human rights or not. See also Rosalind Dixon, 'Creating Dialogue about Socioeconomic Rights: Strong-form versus Weak-form Judicial Review Revisited' (2007) 5 ICON 391; Dennis M Davis, 'Socioeconomic Rights: Has the Promise of Eradicating the Divide between First and Second Generation Rights been Fulfilled?' in Tom Ginsburg and Rosalind Dixon (eds), Comparative Constitutional Law (Edward Elgar Publishing 2011) 519-29; Anna Gamper, 'Relativer Grundrechtsschutz' in Rudolf Feik and Roland Winkler (eds), Festschrift für Walter Berka (Jan Sramek Verlag 2013) 62-72. On the risks of judicial enforcement of constitutional constraints, Mark Tushnet and Juan F González-Bertomeu, 'Justiciability' in Mark Tushnet and others (eds), Routledge Handbook of Constitutional Law (Routledge 2013) 116-18.

22 See, eg, Constitution of Slovakia, art 127(2); Law of the Hungarian Constitutional Court, art 46(1). See also the German Federal Constitutional Court's Rendsburg Illegitimacy Case, 25 BVerfGE 167 (1969), in which the Court held that a constitutional mandate could and had to be directly realised by the courts, unless the law-maker did not do so within due time, even though the Court also spoke of the 'alternative realization of the will of the constitution (...) as far as this is possible without the law-maker'. Further examples are given by Ginsburg and Elkins (n 19) 1445-46.

23 The Austrian Constitutional Court, eg, held that it had no power to declare the unconstitutionality of a total lacuna', since in such a case no legal act exists that could be challenged or repealed (see Constitutional Court of Austria 14.453/1996). In contrast, the Court will be able to repeal a 'partial lacuna', ie a law or provision containing only some partial treatment of a subject matter, eg, because it violates the principle of equality. For the Italian Constitutional Court, see Daniele Butturini, 'Caratteri e Tipologie delle Sentenze Additive di Prestazione' in Daniele Butturini and Matteo Nicolini (eds), Tipologie ed Effetti Temporali delle Decisioni di Incostituzionalità: Percorsi di Diritto Costituzionale Interno e Comparato (Edizioni Scientifiche Italiane 2014) 48-51. On total ('absolute') and partial ('relative') omissions, see Brewer-Carías (n 4) 125-65.

24 In particular, the Supreme Court of India has delivered several judgments including substitute legislation. See Surya Deva, 'India: Constitutional Courts as Positive Legislators: The Indian Experience' in Allan R Brewer-Carías (ed), Constitutional Courts as Positive Legislators: A Comparative Study (CUP 2013) 594600; Chang and others (n 13) 459-61. Critically on similar case law by the Venezuelan Constitutional Chamber, see Brewer-Carías (n 4) 37, 165-71. 
time limit, since constitutions will not always explicitly provide for this. Does this imply that a constitutional court could enact substitute legislation as soon as the respective constitutional provision entered into force and as long as the ordinary law-maker omitted to enact such legislation? Does substitute legislation require constitutional provisions that explicitly request the ordinary law-maker to enact a law, or is substitute legislation an implied power? In other words, does a court have power to enact implementing legislation because the constitution explicitly empowers the court to do so, as in the case of the Constitution of Ecuador, or just because the court considers this to be an implied power falling under, for example, 'remedies for enforcement of rights, ${ }^{25}$ such as orders or writs? It goes without saying that cases without explicit constitutional authorisation for doing so will have to be viewed much more critically. ${ }^{26}$

\subsection{Legislation through interpretation}

A last issue to be referred to here regards judicial law-making through interpretation. ${ }^{27}$ Interpretation by judges should, in Montesquieuan terms, not affect legislation, since the judge is conceived solely as the 'bouche qui prononce les paroles de la Loi. ${ }^{28}$ Still, the 'words of the law' or those of the constitution respectively are often not as explicit as one could wish them to be. As constitutions even more rarely entrench explicit interpretation rules, ${ }^{29}$ so that constitutional courts usually have discretion to develop their own interpretive rules, the distinction between interpretation of a law and the creation of laws by judges is sometimes rather difficult to draw. ${ }^{30}$ When a constitutional court understands a legal term either in a wider sense than the word linguistically, historically or contextually suggests or when it uses a wholly different meaning, this may be equivalent to an amendment of the law. But also where a court understands a term in a narrower sense than suggested by either language, historical genesis or context, this will have a law-making character. It will be as if the positive law-maker had restrained the term by a subsequent legal definition according to which that term was not allowed to be understood in another way. Further, occasions may arise where a linguistic, historical or contextual interpretation might not be compatible or be controversial, and where it will be necessary to opt for only one type of interpretation: either linguistic, historical or contextual. ${ }^{31}$ Even the use of all these interpretive methods may not resolve

25 See Constitution of India, s 32; see, similarly, Constitution of South Africa, ss 8(3), 172(1)(b).

26 Similarly, Brewer-Carías (n 4) 36.

27 See also Stone Sweet (n 5) 827-28; Brewer-Carías (n 4) 29-31.

28 Charles De Secondat, Baron De Montesquieu, De l'Esprit des Lois (Chatelain 1748) vol XI, ch VI.

29 See the comparative survey of constitutions entrenching explicit interpretive rules in Anna Gamper, Regeln der Verfassungsinterpretation (Springer 2012) 7-100. If such rules are entrenched at all, they mostly refer to human rights interpretation, while general rules on constitutional interpretation constitute rare cases.

30 See also Brewer-Carías (n 4) 79-94.

31 See, on the various methods and approaches employed by courts, Chen and Poiares Maduro (n 8) 104-06; Jeffrey Goldsworthy, 'Constitutional Interpretation' in Michel Rosenfeld and András Sajó (eds), The Oxford Handbook of Comparative Constitutional Law (OUP 2012) 692-93. 
doubtful cases which require courts to use further methods. Among these, we often find 'consistency interpretation,' ${ }^{32}$ which means that the doubtful meaning of a law will be interpreted in a way that makes it compatible with superior law, such as the constitution, EU law, ${ }^{33}$ international law ${ }^{34}$ or even foreign law. ${ }^{35}$ In this case, constitutional courts will be required to select one option, even if the constitution does not determine the interpretive method, simply because they are obliged to decide. If courts arbitrarily apply the consistency method, without having previously applied the more orthodox methods, this will be looked at more critically. In both cases, courts will to some extent resemble positive legislators, since they alter (extend, reduce or totally reinvent) a meaning that could be interpreted differently. The question is, however, whether they are constitutionally empowered or even constrained to act in this way or whether their choice stems just from their own preferences.

But even where courts positively alter the law through interpretation, the effect of their 'interpretation' will still be different from that of a properly enacted law. While a law must be obeyed by all courts and authorities, the interpretation by a court does not necessarily have such a binding effect even though this might be desirable ${ }^{36}$. On the one hand, this concerns the difference between common law and civil law systems whose courts follow the stare decisis doctrine in different degrees or not at all. ${ }^{37}$ On the other hand, some interpretation methods may be ex natura unsuited for some courts, as they are limited to apex or constitutional courts. If a constitution provides, for example, that constitutional questions must be referred to a constitutional court by other courts when these other courts apply laws the constitutionality of which appears doubtful to them, it would not be for these courts to use the consistency method. ${ }^{38}$ Rather, they must ask the

32 The requirement to interpret dubious laws as consistent with the constitution is sometimes expressly entrenched in constitutional law (Constitution of Barbados, s 49(6); Constitution of Slovakia, art 152(4); Constitution of Hungary, art 28; Constitution of Ghana, ch IV art 11(6); Constitution of Lesotho, art 156(1); Constitution of Zambia, s 6(1)), but sometimes it just results from the case law of constitutional courts (see, for Austria, Gamper, Regeln der Verfassungsinterpretation (n 29) 217-32). In specific constitutional contexts, particularly those of human rights interpretation, a large variety of constitutions provide further consistency rules (see below n 34 and n 35). In contrast, some constitutions (eg, Constitution of Namibia, art 146) stipulate that the (younger) constitution should be interpreted in consistency with previous laws 'unless the context otherwise indicates'. See also Brewer-Carías (n 4) 32, 73-78.

33 Consolidated Version of the Treaty on European Union [2012] OJ C326/13, art 4(3).

34 See, eg, Constitution of Spain, art 10(2); Constitution of Peru (fourth transitory provision); Constitution of Romania, art 20; Constitution of Ethiopia, art 13(2); Constitution of Timor-Leste, s 23; Constitution of Portugal, art 16(2); Constitution of Cape Verde, art 17(3); Constitution of Guinea-Bissau, art 29(2); Constitution of Maldives, art 68; Constitution of Bolivia, art 13; Constitution of Colombia, art 93; Constitution of Angola, art 26(2); Constitution of Mozambique, art 43; Constitution of Serbia, art 18; Constitution of Mexico, art 1(2); Human Rights Act 1998 (UK) s 3(1).

35 See Constitution of South Africa, s 39(1)(a)-(c); Constitution of the Marshall Islands, art I s 3(1); Constitution of Malawi, s 11; Constitution of Papua New Guinea, s 39.

36 Harding and others (n 5) 7.

37 ibid 8-9.

38 The problem arises in systems with specialised constitutional review in which other courts must ask the constitutional court to resolve constitutional questions instead of resolving them themselves. The application of the consistency method would undermine this requirement, because dubious laws would be 
constitutional court to decide on the constitutionality of the law without anticipating the court's decision. Whether the constitutional court itself applies the consistency method or not, will remain to be decided by that court. So, if a constitutional court declares a law to be consistent with the constitution (even if it is possible that this is not the case), the court will give a restrictive meaning to the wider wording of that law even though there is nothing but doubt that advocates such a meaning. If other courts, however, are prevented from using the consistency method, the effect of the constitutional court's consistency interpretation might not have the force of a law, simply because the same interpretive method is not applied by those other courts. Moreover, apex courts will not be prevented from changing their own interpretation from time to time, ${ }^{39}$ which means that the effect of a previous interpretation might not be permanent-whereas the legislature's law remains in force until a proper amendment procedure has taken place. What we expect from legal certainty (ie clarity, consistency and easy access to the law in force), may not, to the same extent, be guaranteed by courts' interpretation, since the law formally remains as it is, while the courts' interpretation may not be equally binding on all possible enforcers of the law.

An exception to this rule arises in cases when constitutional courts are constitutionally empowered to enact an authoritative interpretation that is as binding as a legal definition entrenched in a law or even a constitutional law. ${ }^{40}$ When, for example, the Austrian Constitutional Court is requested to decide whether a draft federal or regional law is consistent with the federal constitutional distribution of competences, its decision has the 'effect of an authentic interpretation ${ }^{\text {'1 }}$ of federal constitutional law. Actually, the Court interprets a competence in as binding a way as if the federal constitutional lawmaker had enacted a legal definition.

If a legislature disagrees with the interpretation given to its law by a court, it will usually have three options to react. Firstly, the legislature might change the law in a way which excludes the meaning suggested by the court. Secondly, the legislature might, in accordance with the relevant constitution, enact an 'authentic interpretation', which is nothing but a subsequent legal definition of a term or provision. Thirdly, the legislature could enact a law requesting the court to use a certain interpretive method or to prohibit the court from using another method. As these options-which could, moreover,

interpreted as constitutional instead of being submitted to the constitutional court. See Gamper, Regeln der Verfassungsinterpretation (n 29) 217-21.

39 This possibility relativises even strong-form review. See Tushnet, Weak Courts, Strong Rights (n 8) 22.

40 See, with examples, Kasia Lach and Wojciech Sadurski, 'Constitutional Courts of Central and Eastern Europe: Between Adolescence and Maturity’ (2008) J Comp L 212, 221; Brewer-Carías (n 4) 15.

41 See, eg, Constitutional Court of Austria 3055/1956, 4446/1963, 6685/1972, 7780/1976, 16.929/2003. Since the Court is not the federal constitutional law-maker, it cannot enact an 'authentic', but only an 'authoritative' interpretation with the 'effect of an authentic interpretation'. See also Ulrich E Zellenberg, 'Art 138 Abs 2 B-VG' in Karl Korinek and Michael Holoubek (eds), Österreichisches Bundesverfassungsrecht. Textsammlung und Kommentar (4th edn, Verlag Österreich 2001) 19-20; Martin Hiesel, 'Art 138 B-VG' in Benjamin Kneihs and Georg Lienbacher (eds), Rill-Schäffer-Kommentar Bundesverfassungsrecht (11th edn, Verlag Österreich 2013) 71-72. 
encounter some constitutional limits $-{ }^{42}$ show, however, interpretation by courts may indeed induce the law-maker to respond, and the emergence of this (sometimes euphemised) 'dialogue ${ }^{43}$ demonstrates how interpretation and law-making obviously share a common object and are thus strongly interrelated.

\subsection{Hans Kelsen revisited: The distinction between negative and positive legislators}

The survey in the previous sections of this article shows that constitutional courts may possess a rather large variety of legislative powers of either a more positive or negative character. But still, the argument upholds the Kelsenian dualism, namely, that there is more than just a formal distinction between positive and negative legislation, whereas, according to Tom Ginsburg and Zachary Elkins, 'the slight distinction between negative and positive legislation breaks down completely when the court has the power to hold legislative omissions unconstitutional.' ${ }^{44}$ They argue that some courts could set a deadline by which the legislature must act to correct an omission. ${ }^{45}$ They also point out that the distinction between both kinds of legislation in the end refers to the power of initial proposal, because all decisions restricting the proposal, based on certain veto rights, imply a negative law-making power. ${ }^{46}$ However, even if the term 'negative legislation' might be applied to all forms of veto rights in the law-making process, there will still be a difference between pre-enactment and post-enactment scrutiny, because there will only be a law (and not just a legislative proposal) that is challenged before a constitutional court in the latter case. Moreover, there is a considerable difference among different 'veto rights', namely, whether they are exercised unrestrictedly in accordance with political views or, as in the case of constitutional courts, because of the unconstitutionality of a bill. Where constitutional courts are empowered to exercise ex ante scrutiny, their decisions usually do not have the power of an absolute veto, and they often require a previous appeal by another legislative organ. A characteristic of 'negative' legislation must be, though, that a law is indeed repealed. Accordingly, this power requires full authority to unmake a law. When a constitutional court only takes part in a legislative process on the appeal of another body and when its ex ante review is mainly advisory,

42 A constitution might prevent the ordinary law-maker from enacting certain pieces of law or even interpretive methods. Even the constitutional law-maker could encounter some limits, if constitutional amendments taken in response to decisions by the constitutional court threaten the core values of the constitution, provided that the constitution accordingly limits the possibility for constitutional change.

43 See, eg, Rosalind Dixon, 'Constitutional Amendment Rules: A Comparative Perspective' in Tom Ginsburg and Rosalind Dixon (eds), Comparative Constitutional Law (Edward Elgar Publishing 2011) 98. For a more moderate perspective, see Yasuo Hasebe and Cesare Pinelli, 'Constitutions' in Mark Tushnet and others (eds), Routledge Handbook of Constitutional Law (Routledge 2013) 18 ('dialectical relation'). For a more critical view, see Ferreres Comella (n 5) 271.

44 Ginsburg and Elkins (n 19) 1445 (original emphasis).

45 ibid 1445-46.

46 ibid 1444. 
we cannot properly classify this as 'negative legislation' even if we equalized a bill with existing law. ${ }^{47}$

As regards legislative omissions, a vast majority of courts do not command the power to set deadlines let alone the power to enact substitute laws on behalf of the omitting law-maker. However, the setting of a deadline does not, at least, replace positive legislation, and thus heeds the separation of powers. The court requests the legislature to enact a law in concreto, because the constitution (already) requests it in abstracto. A point that Hans Kelsen also considered important for the general distinction between positive and negative legislation is, moreover, that the court does not exert influence on the exact design and content of such a mandated law. ${ }^{48}$ It may thus be doubted whether it is really 'not much of a jump from this type of review to one that explicitly allows the constitutional court to propose legislation. ${ }^{49}$ As far as this latter power may be exercised by courts at all-as we have seen, in extremely few cases-the gap appears rather larger. While the right to initiate laws implies the court's free choice of 'political' design, the setting of a deadline for the legislature neither implies any kind of 'political' impact on the content of that law nor does it replace the responsible legislative body by the constitutional court. The court actually does nothing but 'translate' a constitutional provision, requesting that an ordinary law comply with that provision within a concrete time period. Whether the law-maker really obeys the time limit, and accordingly enacts a law, remains to be seen.

Therefore, the categories belonging to the complex spectrum of judicial lawmaking need to be handled carefully and distinctly. In particular, we need to distinguish between any kind of contribution to or participation in a legislative process and full responsibility for positive or negative legislation. We need to be cautious about the conditions for positive or negative legislation and the respective scope and discretion given to legislatures or constitutional courts. While legislatures retain full power to make or unmake a law, constitutional courts only partially possess concurrent powers of law-making. Lastly, we need to distinguish between negative or positive law-making by constitutional courts either in the sense that they act as a legislature or that they engage in any kind of interpretation or judicial decision-making. It is a matter of course that constitutional courts create a type of law, because they deliver judgments. The relevant question in this context, though, is whether they also have power to make or unmake laws as a quasi-legislature. As a consequence, not every kind of decision-making power or interpretation by constitutional courts should be considered as being equivalent to a legislature's law-making power.

47 The same would be said with regard to any other organ without sufficient power to positively prevent a law from being enacted or to repeal it, such as a second chamber with only a suspensive veto right or a head of state that is constitutionally constrained not to deny its assent to a law or any court under weak-form review that could not repeal a law but just convey a message on its constitutionality.

48 Kelsen, 'Wesen und Entwicklung der Staatsgerichtsbarkeit' (n 2) 56. Similarly, Brewer-Carías (n 4) 29.

49 Ginsburg and Elkins (n 19) 1446. 


\section{The democratic dilemma of constitutional courts and the separation of powers}

The diverse powers of constitutional courts regarding negative or even positive legislation to some extent overthrow the separation of powers-at least, if we conceive it as a system of clearly divided departments each remaining in complete isolation, a state of affairs that probably no constitutional system has really managed. However, a main worry here is not just the relativisation of the separation of powers doctrine as such, but also that the exercise of legislative powers by the judiciary entails a loss of democracy. ${ }^{50}$ This loss becomes evident when we compare the degree of democracy inherent in the creation process of legislatures with the appointment of constitutional judges. If we conceive a legislature as the entirety of the different organs involved in a legislative process (for example, governments, parliaments, heads of states or perhaps even constituent states), constitutional courts might be part of it inasmuch as they propose laws or exercise ex ante constitutional review. For the sake of the argument, therefore, we need to compare the democratic legitimacy of constitutional courts with non-judicial bodies that are typically responsible for law-making and this is, first and foremost (at least ideally), ${ }^{51}$ a parliament.

In terms of organisation, hardly any constitutional court will ever be able to keep up with a parliament, since constitutional judges are, as a rule, appointed and not elected by the people. ${ }^{52}$ At second glance, we may detect some thin democratic legitimacy even there, since the appointing bodies, such as heads of states, governments or parliaments, themselves possess some kind of direct or indirect democratic legitimacy, though still much weaker than that of a directly elected body; there will be even less legitimacy where associations of lawyers or academies of sciences or courts propose or appoint judges. ${ }^{53}$ At any rate, national constitutional courts' judges are hardly ever elected by the people, probably with good reasons; ${ }^{54}$ a rare exception is, for example, the Bolivian Constitutional Court. ${ }^{55}$ Therefore, from an organisational viewpoint, constitutional courts cannot normally claim as much democratic legitimacy as a parliament. They cannot even claim as much democratic legitimacy as that of non-parliamentary bodies

50 Brewer-Carías (n 4) 36-40.

51 Anthony W Bradley and Cesare Pinelli, 'Parliamentarism' in Michel Rosenfeld and András Sajó (eds), The Oxford Handbook of Comparative Constitutional Law (OUP 2012) 665-67.

52 Harding and others (n 6) 12-14; Lach and Sadurski (n 40) 213-14.

53 See, Harding and others (n 5) 13-14. A particularly far-reaching example is constituted by the Russian Constitutional Law on the Constitutional Court, art 9.

54 According to Hans Kelsen, Wer soll der Hüter der Verfassung sein? (Walther Rothschild 1931) 50-51, nothing would prevent a democratic organisation of a constitutional court, including the direct election of the judges by the people, even though this might not be the 'most practical' way of creation.

55 See Constitution of Bolivia, art 198. See also Anna Gamper, 'Verfassungsrechtliche Voraussetzungen des öffentlich-rechtlichen Richteramts in Österreich und Europa' in Karim Giese and others (eds), Verwaltung im demokratischen Rechtsstaat-Festschrift für Harald Stolzlechner zum 65. Geburtstag (Verlag Österreich 2013) 151. 
usually taking part in a legislative process, such as governments or (republican) heads of states, since these bodies are normally either elected by parliament or appointed by an elected head of state or directly elected by the people.

How can the exercise of legislative powers by constitutional courts be reconciled with the principle of democracy? To some extent, ${ }^{56}$ the separation of powers requires democratic concessions. The repeal of laws on account of a finding of unconstitutionality by an independent court is essential for a system of checks and balances. ${ }^{57}$ However, the more constitutional courts engage in positive law-making, the more tensions will arise. The separation of powers will not legitimate independent courts as positive legislators, since this interference with the domain of the legislature raises the 'counter-majoritarian difficulty. ${ }^{58}$ Why have a constitutional court, with less democratic legitimacy than the legislature, rivalling that legislature? This will not be the case, though, when, for example, a constitutional court exercises ex ante constitutional review at the proposal of a legislative organ, since the court exercises its competences only because of that other organ's request. However, where a constitutional court initiates laws of its own free will or where it even enacts substitute legislation because of the legislature's fault, there remain two apparent deficits. Firstly, the constitutional court cannot claim the democratic legitimacy of a legislature in terms of organisation. And secondly, the separation of powers does not furnish constitutional courts exercising positive legislative powers with 'compensational' legitimacy.

\section{Functional democracy}

In order to assess the democratic legitimacy of constitutional courts, however, it is not enough to look at the way their judges are appointed, and whether they are bound to any kind of democratic control. The simple answer to this would be that judges are not normally elected by the people and that, due to the desired independence of these courts, they can neither be bound to instructions nor be subject to any kind of accountability towards parliament or the electorate. ${ }^{59}$ At the utmost, they will have to leave office after a fixed period of time and, in order to be re-appointed (if this is possible at all), need

56 Several other partially similar 'grounds of legitimacy of judicial power' are listed by Daniel Smilov, 'The Judiciary: The Least Dangerous Branch?' in Michel Rosenfeld and András Sajó (eds), The Oxford Handbook of Comparative Constitutional Law (OUP 2012) 863. Hasebe and Pinelli (n 42) 16-17 emphasise the legitimising effect of human rights protection as being 'inextricably connected with the democracy's functioning. However, judicial law-making does not always involve human rights, and political rights, on the exercise of which parliaments base their legitimacy, are, in turn, part of human rights.

57 Smilov (n 56) 864.

58 Alexander M Bickel, The Least Dangerous Branch: The Supreme Court at the Bar of Politics (Bobbs-Merrill 1962) passim.

59 Lach and Sadurski (n 40) 213-14. 
the support of other bodies that propose or appoint them. ${ }^{60}$ They are also bound to the relevant constitution and, as far as this is compatible with the exercise of constitutional review, even with ordinary laws, but as long as there is no supervising authority that examines whether courts act in line with the rule of law, this obligation will be a lex imperfecta.

Democracy and constitutional courts have a much more complex relationship, though. The ingenious invention of constitutional review, brilliantly spelt out in the above quoted Federalist No 78, builds on the idea of functional democracy. Irrespective of democratic deficits regarding their appointment and independence, it is for constitutional courts to protect the constitution. This function is essentially democratic, since in liberal democracies $^{61}$ the constitution is the most democratic of all sources of law. In written constitutions, this becomes manifest in the amendment provisions, where usually a larger quorum and majority in parliament are needed in order to create constitutional law. Often, additional requirements such as a referendum, parliamentary elections or the particular assent of second chambers or regional parliaments are stipulated. ${ }^{62}$ In short, it needs more democratic input to create and amend the constitution than to create any other piece of law. As a consequence, the constitution possesses more democratic legitimacy than other sources of law. Constitutional courts thus receive democratic legitimacy through their function to protect the constitution in order to safeguard that the will of the people, as expressed in the constitution, is obeyed. This will definitely be the case when an unconstitutional law is repealed; it will also be the case when a draft law is not enacted on account of a constitutional court's ex ante decision that it would be unconstitutional. If a constitutional court decides on whether the repeal of a revoking law does or does not reinstate the revoked previous law, this will, in terms of democracy, have a zero-sum effect, since both decisions could be legitimised with a historical will of the legislature that first enacted the law and revoked it afterwards. But does the democratic function of 'guardian of the constitution ${ }^{23}$ refer to all those other kinds of judicial law-making identified above?

Let us take the rare example of a constitutional court's right to initiate laws. ${ }^{64}$ This power is not exercised in order to defend the constitution from the lawmaker's interference; rather, the court itself proposes a law which may or may not be constitutional. Indeed, it may be expected that a constitutional court will take care that its proposal is constitutional. It may also be supposed that the ratio behind this power lies in the expectation that constitutional courts will be able to deal with delicate

60 See also Gamper, 'Verfassungsrechtliche Voraussetzungen des öffentlich-rechtlichen Richteramts in Österreich und Europa' (n 55) 147-49.

61 See Dieter Grimm, 'Types of Constitutions' in Michel Rosenfeld and András Sajó (eds), The Oxford Handbook of Comparative Constitutional Law (OUP 2012) 116-19.

62 See Claude Klein and András Sajó, 'Constitution-Making: Process and Substance' in Michel Rosenfeld and András Sajó (eds), The Oxford Handbook of Comparative Constitutional Law (OUP 2012) 438-40.

63 See Kelsen, Wer soll der Hüter der Verfassung sein? (n 54) in his famous dispute with Carl Schmitt.

64 See above 2.4 . 
matters such as constitutional changes or constitutional adjudication in an expert and hopefully constitutional way. Nevertheless, none of those constitutions which empower constitutional courts to initiate laws positively command that such a legislative proposal must be in conformity with the constitution. Admittedly, the legislature may successfully prevent the proposal from becoming a law, but this does not change the rather undemocratic origin of the proposal itself.

Similarly problematic are those cases of positive legislation where a constitutional court sets a deadline for an omitting legislature, or perhaps even itself enacts substitute legislation. If a constitutional court reminds the legislature to enact a law that is stipulated by the constitution-sometimes in only an implied way- ${ }^{65}$ this will be done with a view to protecting the constitution. The setting of fixed deadlines may be already critical, since constitutions normally are not explicit on that issue. ${ }^{66}$ But when a constitutional court itself enacts a substitute law, without being explicitly empowered to do so by the constitution, democratic tensions will increase dramatically, since the court positively designs the content of that law instead of the legislature. Although the constitutional request for a law is satisfied in that way, will the constitution not be also violated if a constitutional court assumes implied responsibility for a task explicitly assigned to another branch? And if the constitution is thus violated, then will the argument of functional democracy still be valid?

Lastly, functional democracy does not legitimise any kind of 'law-making through interpretation'. Most constitutions do not provide explicit rules on interpretation, while they usually entrench explicit rules on law-making processes, in which constitutional courts play a minor or no role at all. It is evident that most constitutions do not provide alternative processes of law-making, but that they assign this role to the-in principle, unrivalled-legislature. Again, it would be a violation of the constitution if constitutional courts thus violated the legislature's monopoly, so that the argument of functional democracy would not apply. The problem here is rather the legal limbo between interpretation and law-making, since there may be exceptional cases, such as analogies, where the very purpose that was intended by the legislature, as it is assumed, endorses judicial law-making. ${ }^{67}$ Another interesting example is the 'consistency method' according to which the constitutional court upholds an ordinary law by interpreting it in a way that is consistent with the constitution. This interpretation avoids a repeal of the law and thus respects the democratic authority of the law-maker as well as the constitution with which the ordinary law is made compatible. Nevertheless, the consistency method might not be applied by other courts and authorities, which implies that the constitution might still be violated by a non-consistent interpretation, so that there will be more uncertainty than in the case of a repeal.

65 Constitutions do not always expressly require an implementing law (see, however, above n 21) but simply set out certain aims and objectives.

66 Where constitutions expressly require a law, this is normally not done with an exact time limit.

67 See Goldsworthy (n 31) 693. 


\section{Conclusions}

The democratic dilemma of constitutional courts is resolvable, even though their judges continue to be appointed instead of being elected. The condition, however, is that constitutional courts only perform those functions that protect the constitution. This condition also implies that constitutional courts only perform those functions that the constitution intends them to have, which is not equivalent to well-meant endeavours to 'realise' the constitution under all circumstances. In other words, any constitutional purpose cannot legitimate any interference by constitutional courts. Where constitutions explicitly authorise a constitutional court to rival the legislature outside the context of protecting the constitution, it could be argued that their democratic legitimacy simply stems from the fact that the constitution itself, being the most intensive expression of the will of the demos, empowers them to do so. Quite apart from other infringed constitutional principles such as the separation of powers, however, such a constitution will nevertheless be less democratic than a constitution that entrusts positive law-making to the people or its (directly or indirectly) elected representatives only. Otherwise, any constitution would have to be called democratic whatever its content may be, simply because it was the constitution originally enacted by the people. This is related to the question-which will not be studied here-of whether the demos might deprive itself of its power if it decided to do so in a constitutional way.

Democratic legitimacy matters-also for constitutional courts. The very concept of the 'will (...) of the people, declared in the Constitution', by which 'judges ought to be governed ${ }^{368}$, gave birth to constitutional review and to constitutional courts worldwide. Jeopardising democracy thus means jeopardising themselves. 